\title{
PERTANGGUNG JAWABAN DALAM PERSEROAN TERBATAS YANG PENGURUSANNYA DILAKUKAN OLEH ANGGOTA DEWAN KOMISARIS PASCA UU CIPTA KERJA
}

\author{
Shenti Agustini; Fakultas Hukum Universitas Internasional Batam, \\ Jl. Gajah Mada, Baloi - Sei Ladi, Batam 29442; E-mail: shenti_monroe@yahoo.com
}

\begin{abstract}
Abstrak
Banyak pelaku usaha menggunakan badan hukum perseroan terbatas untuk menjalankan usahanya, namun dalam prakteknya, banyak ditemukan susunan pemegang saham dan organnya terdiri dari perorangan-perorangan yang masih mempunyai hubungan keluarga, sehingga tidak sedikit perorangan yang menjabat sebagai anggota dewan komisaris tanpa melalui tata cara yang benar dalam melakukan berbagai tindakan pengurusan atas nama perseroan, bahkan mengadakan perikatan terhadap pihak ketiga atas nama perseroan padahal jabatannya adalah sebagai dewan komisaris, sehingga tidak menutup kemungkinan mengalami kerugian. Selain itu, pengelolaan perusahaan dengan tidak benar dapat menimbulkan kerugian yang juga akan merugikan pihak ketiga yang mengadakan perikatan dengan perseroan tersebut. Penelitian ini bertujuan untuk mengetahui upaya hukum yang dapat ditempuh pihak ketiga yang dirugikan oleh dewan komisaris dari suatu perseroan terbatas yang melakukan pengurusan terhadap usaha perseroan tersebut.
\end{abstract}

Kata Kunci: Tanggung Jawab, Perseroan Terbatas, Dewan Komisaris

\begin{abstract}
Many business actors use a limited liability company to run their business. However, in practice, it is found that the composition of shareholders and organs consists of individuals who still have family relationships, so that not a few individuals serve as members of the board of commissioners without going through the correct procedure in carrying out various management actions on behalf of the company, even entering into agreements with third parties on behalf of the company even though his position is as a board of commissioners, so it is possible to experience losses. In addition, improper company management can cause losses that will harm third parties who enter into an engagement with the company. This study aims to determine the legal remedies that can be taken by third parties who are disadvantaged by the board of commissioners of a limited liability company that manages the company's business.
\end{abstract}

Keywords: Responsibility, Limited Liability Company, Board of Commissioners

\section{PENDAHULUAN}

\section{Latar Belakang}

Salah satu permasalahan utama yang harus diselesaikan di bumi Indonesia saat ini adalah mengurangi jumlah pengangguran yang ada dengan membuka lapangan pekerjaan yang sebanyak-banyaknya, jika hal tersebut tidak bisa dilakukan maka demokrasi ekonomi di Indonesia akan masih harus menempuh jalan yang sangat panjang untuk mewujudkan kesejahteraan bagi seluruh masyarakat Indonesia. Kebijakan Pemerintah Indonesia beberapa tahun belakangan ini dikeluarkan untuk mengatasi permasalahan kurangnya lapangan pekerjaan, hal ini tidak hanya menjadi perhatian lembaga eksekutif saja, lembaga legislatif juga belakangan ini semaksimal mungkin membuat rancangan peraturan-peraturan dan mengesahkan racangan perundangundangan yang diharapkan dapat meningkatkan jumlah lapangan pekerjaan untuk menyerap pengangguran yang ada. 
Undang-Undang Nomor 11 Tahun 2020 tentang Cipta Kerja (untuk selanjutnya disebut UU Cipta Kerja) merupakan salah satu peraturan yang dibuat untuk mengatasi permasalahan di atas. Bahkan sebelum itu pada tahun 2016 pemerintah mengeluarkan Peraturan Pemerintah Nomor 29 Tahun 2016 tentang Perubahan Modal Dasar Perseroan Terbatas (untuk selanjutnya disebut PP No. 29/2016) dimana modal dasar untuk Perseroan Terbatas yang sebelumnya minimal Rp 50.000.000,- (lima puluh juta Rupiah) sebagaimana diatur dalam Undang-Undang Nomor 40 Tahun 2007 tentang Perseroan Terbatas (untuk selanjutnya disebut UU Perseroan terbatas) dapat dikesampingkan dengan kesepakatan para pendiri Perseroan Terbatas.

Peraturan-peraturan tersebut di atas mempermudah bagi pelaku usaha yang ingin menjalankan usahanya dengan badan usaha jenis perseroan terbatas. Sebagaimana yang kita ketahui peseroan terbatas merupakan badan usaha yang berbadan hukum dimana terdapat pemisahan kekayaan antara kekayaan perseroan dengan kekayaan pribadi dari para pemegang saham dan kewenangan dari organ-organ yang ada dalam suatu Perseroan Terbatas sudah diatur sedemikian rupa oleh UU Perseroan Terbatas, sehingga bentuk badan usaha perseroan terbatas menurut penulis merupakan bentuk yang paling baik dibandingkan badan usaha lainnya yang ada di Indonesia.

Subtansi tersebut mengubah secara signifikan landscape hukum Perseroan Terbatas (PT) di Indonesia khususnya yang diatur dalam UU Perseroan Terbatas. Ketentuan mengenai PT diatur dalam Bab IV Kemudahan Berusaha Bagian Keempat tentang Perseroan Terbatas Pasal 111. ${ }^{1}$ Beberapa perubahan signifikan landscape hukum PT diantaranya sebagai berikut: Pertama, pengecualian untuk dua pemegang saham. Pada dasarnya, perseroan terbatas perlu didirikan oleh paling sedikit dua subjek hukum berdasarkan perjanjian. Di dalam Undang-Undang Cipta Kerja, perseroan terbatas meliputi badan hukum perorangan jika memenuhi kriteria usaha mikro dan kecil. Dengan demikian, setiap orang dapat mendirikan suatu perseroan terbatas dan memiliki sahamnya seorang diri, sepanjang perseroan tersebut termasuk dalam kategori usaha mikro dan kecil. ${ }^{2}$ Lebih lanjut, perubahan Undang-Undang Perseroan Terbatas juga mengatur bahwa pengecualian untuk dua pemegang saham berlaku bagi persero yang seluruh sahamnya dimiliki oleh negara, badan usaha milik daerah, badan usaha milik desa, perseroan yang mengelola bursa efek, lembaga kliring dan penjaminan, lembaga penyimpanan dan penyelesaian, dan lembaga lain sesuai dengan Undang-Undang tentang Pasar Modal dan perseroan yang memenuhi kriteria untuk usaha mikro dan kecil. Kedua, status badan hukum. Sebelum perubahan, perolehan status badan hukum bagi perseroan terjadi pada tanggal diterbitkannya keputusan Menteri Hukum dan Hak Asasi Manusia tentang pengesahan badan hukum. Namun, setelah perubahan, perolehan

\footnotetext{
1 Munawar Kholil. (26 Oktober 2020). "Catatan Kritis Perubahan Landscape Hukum Perseroan Terbatas dalam Undang-Undang Cipta Kerja". Jurnal RechtsVinding, h. 1-4.

2 Pasal 109 angka 1 Undang-Undang Cipta Kerja mengatur bahwa "Perseroan Terbatas, yang selanjutnya disebut Perseroan, adalah badan hukum yang merupakan persekutuan modal, didirikan berdasarkan perjanjian, melakukan kegiatan usaha dengan modal dasar yang seluruhnya terbagi dalam saham atau badan hukum perorangan yang memenuhi kriteria usaha mikro dan kecil sebagaimana diatur dalam perundang-undangan mengenai usaha mikro dan kecil."
} 
status badan hukum perseroan terjadi setelah didaftarkan kepada Menteri dan mendapatkan bukti pendaftaran. ${ }^{3}$ Ketiga, jumlah modal dasar. Ketentuan mengenai modal dasar juga telah diubah oleh Undang-Undang Cipta Kerja. Sebelumnya, besaran modal dasar adalah paling sedikit Rp 50.000 .000 (lima puluh juta rupiah). Saat ini, besaran modal dasar perseroan ditentukan berdasarkan keputusan pendiri perseroan. ${ }^{4}$ Keempat, biaya administrasi pemerintah pada perseroan. Biaya-biaya yang terkait dengan administrasi pemerintah pada perseroan terbatas sebelumnya merujuk pada peraturan pemerintah, namun setelah adanya amandemen, biaya-biaya tersebut merujuk pada undang-undang dan peraturan di bidang penerimaan negara bukan pajak. ${ }^{5}$ Kelima, perseroan yang memenuhi kriteria usaha mikro dan kecil. Undang-Undang Cipta Kerja menambahkan 10 pasal baru mengenai usaha mikro dan kecil. Bahwa perseroan yang memenuhi kriteria usaha mikro dan kecil dapat didirikan oleh hanya satu orang. ${ }^{6}$ Adapun, pendirian perseroan untuk usaha mikro dan kecil dilakukan berdasarkan surat pernyataan pendirian yang dibuat dalam Bahasa Indonesia7dan didaftarkan secara elektronik kepada Menteri. ${ }^{8}$ Selain itu, bahwa dalam pendirian badan hukum perseroan untuk usaha mikro dan kecil diberikan keringanan biaya. ${ }^{9}$ Direksi perseroan untuk usaha mikro dan kecil menjalankan pengurusan perseroan sesuai dengan maksud dan tujuan perseroan. ${ }^{10}$ Direksi perseroan wajib membuat laporan keuangan dalam rangka mewujudkan tata kelola perseroan yang baik. ${ }^{11}$ Kemudian, pendiri perseroan untuk usaha mikro dan kecil hanya dapat mendirikan satu perseroan dalam satu tahun. ${ }^{12}$ Untuk perseroan untuk usaha mikro dan kecil, pemegang sahamnya merupakan orang perorangan.13 Pemegang saham perseroan untuk usaha mikro dan kecil tidak bertanggung jawab secara pribadi atas perikatan yang dibuat atas nama perseroan dan tidak bertanggung jawab atas kerugian perseroan melebihi saham yang

\footnotetext{
${ }^{3}$ Pasal 7 ayat (4) Undang-Undang Perseroan Terbatas yang telah diubah dengan Undang-Undang Cipta Kerja

${ }^{4}$ Pasal 32 ayat (2) Undang-Undang Perseroan Terbatas yang telah diubah dengan Undang-Undang Cipta Kerja

${ }^{5}$ Pasal 153 Undang-Undang Perseroan Terbatas yang telah diubah dengan Undang-Undang Cipta Kerja

${ }^{6}$ Pasal 153A ayat (1) Undang-Undang Perseroan Terbatas yang telah diubah dengan UndangUndang Cipta Kerja

7 Pasal 153A ayat (2) Undang-Undang Perseroan Terbatas yang telah diubah dengan UndangUndang Cipta Kerja

8 Pasal 153B ayat (1) Undang-Undang Perseroan Terbatas yang telah diubah dengan UndangUndang Cipta Kerja

9 Pasal 153I ayat (1) Undang-Undang Perseroan Terbatas yang telah diubah dengan UndangUndang Cipta Kerja

${ }^{10}$ Pasal 153D ayat (1) Undang-Undang Perseroan Terbatas yang telah diubah dengan UndangUndang Cipta Kerja

${ }_{11}$ Pasal 153F ayat (1) Undang-Undang Perseroan Terbatas yang telah diubah dengan UndangUndang Cipta Kerja

${ }^{12}$ Pasal 153E ayat (2) Undang-Undang Perseroan Terbatas yang telah diubah dengan UndangUndang Cipta Kerja

${ }^{13}$ Pasal 153E ayat (1) Undang-Undang Perseroan Terbatas yang telah diubah dengan UndangUndang Cipta Kerja
} 
dimiliki, ${ }^{14}$ ketentuan tersebut berlaku selama: (a) persyaratan perseroan sebagai badan hukum sudah terpenuhi; (b) pemegang saham tidak memiliki itikad buruk (secara langsung maupun tidak langsung) memanfaatkan perseroan untuk kepentingan pribadi; (c) pemegang saham bersangkutan tidak terlibat dalam perbuatan melawan hukum yang dilakukan oleh perseroan; atau (d) pemegang saham tidak secara melawan hukum menggunakan kekayaan perseroan, yang mengakibatkan perseroan menjadi tidak cukup untuk melunasi utang perseroan. ${ }^{15}$ Pembubaran perseroan untuk usaha mikro dan kecil dilakukan oleh RUPS yang dituangkan dalam pernyataan pembubaran dan diberitahukan secara elektronik kepada Menteri. ${ }^{16}$ Apabila perseroan untuk usaha mikro dan kecil tidak lagi memenuhi kriteria sebagai usaha mikro dan kecil, maka perseroan wajib mengubah statusnya menjadi perseroan sebagaimana dimaksud dalam ketentuan peraturan perundang-undangan yang berlaku. ${ }^{17}$

Masyarakat Indonesiapun ternyata menyambut baik kebijakan-kebijakan yang mempermudah untuk mendirikan suatau perseroan terbatas, sekarang banyak kita lihat suatu usaha yang dulunya dijalankan atas nama perorangan, saat ini dijalankan dengan menggunakan badan usaha perseroan terbatas, namun ternyata pada prakteknya banyak yang menjalankan usaha dengan badan usaha perseroan terbatas tidak mengerti mengenai perseroan terbatas itu sendiri, mereka yang menduduki jabatan sebagai pemegang saham, direksi dan dewan komisaris banyak yang tidak tahu apa kewenangan yang mereka punya dan sampai mana batasan-batasan dari jabatan tersebut.

Hal tersebut sering terjadi dikarenakan mereka hanya menggunakan badan usaha perseroan terbatas untuk keperluan formalitas dan mendengar bahwa ada pemisahan kekayaan antara perseroan dengan pribadi sehingga jika ada kerugian mereka tidak harus bertanggung jawab sampai ke kekayaan pribadi. Hal tersebut tidaklah sepenuhnya salah namun sudah pasti ada pemahaman yang kurang mendalam dari pemegang saham, direksi dan dewan komisaris jika berpikiran sesempit itu.

Perseroan terbatas yang tidak dikelola sesuai dengan aturan yang ada berpotensi untuk merugi dan menimbulkan kerugian baik terhadap perseroan itu sendiri maupun kepada pihak ketiga yang mempunyai hubungan hukum terhadap perseroan tersebut. Dalam hal ini banyak terjadi dimana anggota dewan komisaris yang tugasnya adalah melakukan pengawasan ikut melakukan pengurusan juga dalam perseroan terbatas, bahkan ada dewan komisaris yang bertindak untuk dan atas nama perseroan terbatas saat mengadakan perikatan dengan pihak ketiga.

Seperti yang sudah dijelaskan sebelumnya kekurangan pemahaman atas perseroan terbatas tidak hanya dialami oleh para pemegang saham, direksi dan dewan komisarinya

${ }_{14}$ Pasal 153J ayat (1) Undang-Undang Perseroan Terbatas yang telah diubah dengan UndangUndang Cipta Kerja

${ }_{15}$ Pasal 153J ayat (2) Undang-Undang Perseroan Terbatas yang telah diubah dengan UndangUndang Cipta Kerja

${ }^{16}$ Pasal 153G ayat (1) Undang-Undang Perseroan Terbatas yang telah diubah dengan UndangUndang Cipta Kerja

17 Pasal $153 \mathrm{H}$ ayat (1) Undang-Undang Perseroan Terbatas yang telah diubah dengan UndangUndang Cipta Kerja 
saja, bahkan maksyarakat pada umumnya juga kurang mengerti mengenai hak tersebut sehingga wajar saja jika ada pihak ketiga yang tidak mempermasalahkan jika seorang anggota dewan komisarislah yang bertindak untuk dan atas nama perseroan saat menagdakan perikatan dengan mereka.

Permasalahan yang kemudian terjadi yaitu ketika perseroan terbatas tersebut mengalami kerugian dan tidak bisa memenuhi kewajiban-kewajibannya kepada pihak ketiga, lantas bagaimana pertanggungjawaban atas kerugian yang dialami pihak ketiga, apakah itu tanggung jawab dari perseroan atau dari anggota dewan komisaris yang mengadakan perikatan tersebut. Hal inilah yang menarik minat Penulis untuk mengadakan penelitian ini, tujuannya adalah untuk mengetahui pertanggung jawaban dewan komisaris yang melakukan pengurusan perseroan terbatas.

\section{Rumusan Masalah}

Berdasarkan latar belakang tersebut di atas, peneliti akan meneliti mengenai bagaimana pertanggungjawaban anggota Dewan Komisaris yang melakukan tindakan pengurusan dalam perseroan terbatas pasca pemberlakuan UU Cipta Kerja.

\section{METODE PENELITIAN}

Meuwissen seorang ahli hukum membedakan antara ilmu hukum normatif dan ilmu hukum empiris, spesifik mengenai ilmu hukum normatif dia menyebutnya sebagai sesuatu yang bersifat sui generis, yang artinya tidak ada bentuk ilmu lain yang dapat dibandingkan dengan ilmu hukum, sehingga menurutnya ilmu hukum normatif mempunyai peran vital dalam pendidikan di universitas. ${ }^{18}$ Oleh karena itu, dalam penelitian ini, peneliti menggunakan metode penelitian normatif dengan menggunakan pendekatan undang-undang (statute approach) yang dilakukan dengan cara menelaah perundang-undangan dan peraturan-peraturan lain yang berkaitan dengan pembahasan. ${ }^{19}$

\section{PEMBAHASAN}

\section{A. Implementasi Pertanggungjawaban dalam Perseroan Terbatas}

Perseroan terbatas adalah suatu badan usaha berbadan hukum yang didirikan berdasarkan perjanjian, serta melakukan kegiatan usaha dengan modal dasar yang seluruhnya terbagi dalam bentuk saham dan memenuhi syarat-syarat yang telah ditetapkan oleh peraturan perundang-undangan (Soedjono Dirjosisworo). ${ }^{20}$ Adapun pendapat lain mengenai definisi perseroan terbatas yaitu perseroan terbatas merupakan persekutuan modal yang berbentuk badan hukum, namun badan hukum ini tidak disebut persekutuan melainkan perseroan, hal tersebut dikareakan modal dari badan hukum itu terdiri dari sero-sero atau saham-saham yang dimilikinya (H.M.N

\footnotetext{
18 Peter Mahmud Marzuki. (2011). Pengantar Ilmu Hukum. Jakarta: Prenada Media Group, h. 34-35.

19 Ibid, h. 131.

20 Soedjono Dirjosisworo. (1997). HukumPerusahaan Mengenai Bentuk-bentuk Perusahaan (Badan Usaha) di Indonesia, Bandung: Mandar Maju, h. 48.
} 
Purwosutjipto). ${ }^{21}$ Sedangkan jika melihat definisi perseroan terbatas pada UU Cipta Kerja, secara normatif maka definisi perseroan terbatas adalah:

"Perseroan terbatas yang selanjutnya disebut Perseroan, adalah badan hukum yang merupakan persekutuan modal, didirikan berdasarkan perjanjian, melakukan kegiatan usaha dengan modal dasar yang seluruhnya terbagi dalam saham atau Badan Hukum perorangan yang memenuhi kriteria Usaha Mikro dan Kecil sebagaimana diatur dalam peraturan perundang-undangan mengenai Usaha Mikro dan Kecil."

Terdapat perubahan definisi mengenai perseroan terbatas dalam UU Cipta Kerja, hal ini dikarenakan adanya peraturan baru yang mengatur bahwa Perseroan Terbatas dapat didirikan oleh 1 (satu) orang, sehingga menurut penulis sudah sewajarnya definisi perseroan terbatas yang sebelumnya diatur dal UU Perseroan Terbatas dirubah, hal ini perlu agar mencegah adanya pertentangan antara definisi perseroan dengan ketentuan yang mengatur mengenai perseroan terbatas yang didirikan 1 (satu) orang.

Adapun pertanggung jawaban organ dalam perseroan terbatas dapat diuraikan sebagai berikut:

1. Rapat Umum Pemegang Saham

Menurut Pasal 75 UU Perseroan Terbatas, organ RUPS memiliki kewenangan yang tidak dimiliki organ lainnya yaitu direksi dan dewan komisaris. Dalam forum RUPS para pemegang saham berhak memperoleh informasi atau keterangan mengenai perseroan dari direksi dan dewan komisaris dengan catatan sepanjang hal tersebut berkaitan dengan agenda rapat dan tidak bertentangan dengan kepentingan perseroan.

Jika menelaah UU Perseroan Terbatas maka kewenangan RUPS antara lain adalah sebagai berikut:

a. Menerima atau mengambil alih semua hak dan kewajiban yang muncul dari tindakan-tindakan hukum yang dilakukan oleh para pendiri atau kuasanya;

b. Memberi persetujuan terhadap segala perbuatan hukum atas nama perseroan yang dilakukan seluruh anggota direksi, dewan komisaris dan para pendiri dengan syarat semua pemegang saham harus hadir dalam RUPS dan seluruh pemegang saham menyetujuinya dalam RUPS;

c. Merubah anggaran dasar perseroan;

d. Memberi persetujuan untuk pembelian kembali atau pengalihan lebih lanjut saham yang dikeluarkan oleh perseroan;

e. Menyetujui penambahan dan pengurangan modal dasar, modal ditempatkan dan modal disetor perseroan;

f. Menyetujui rencana kerja tahunan jika anggaran dasar mengatur;

g. Memberu persetujuan laporan tahunan dan pengesahan laporan keuangan serta laporan tugas pengawasan dari dewan komisaris;

h. Memutuskan penggunan laba bersih, termasuk memutuskan jumlah penyisihan untuk cadangan wajib dan cadangan lain;

${ }^{21}$ H.M.N. Purwosutjipto. (1979). Pengertian Pokok Hukum Dagang Indonesia. Jakarta: Djambatan, h. 85. 
i. Mengangkat dan memberhentikan anggota direksi serta menentukan pembagian tugas pengurusan perseroan antara anggota direksi;

j. Menetapkan besarnya gaji dan tunjangan anggota direksi;

k. Memberi persetujuan kepada direksi untuk mengalihkan kekayaan perseroan atau menjaminkan kekayaan perseroan apabila nilai kekayaan tersebut melebihi dari 50 $\%$ (lima puluh persen) jumlah kekayaan bersih perseroan;

1. Memberi persetujuan kepada direksi untuk memohon pailit

m. Mengangkat dan memberhentikan anggota dewan komisaris;

n. Menetapkan besarnya gaji dan tunjangan anggota dewan komisaris;

o. Memberi persetujuan mengenai penggabungan, peleburan dan pengambil alihan atau pemisahan;

p. Memberi keputusan atas pembubaran perseroan;

q. Menerima pertanggung jawaban likuidator atas penyelesaian likuidasi. ${ }^{22}$

Dari penjelasan diatas dapat dilihat kewenangan RUPS sangat banyak dan tidak dimiliki oleh organ lainnya, namun walaupun kewenangan RUPS sangatlah banyak, untuk mewakili perseroan didalam maupun diluar pengadilan dan yang berwenang melakukan pengurusan perseroan sehari-harinya adalah direksi yang akan dibahas pada bagian selanjutnya.

2. Dewan Komisaris

Pengurusan perseroan yang dilakukan direksi diawasi oleh dewan komisaris baik secara umum dan/atau khusus yang dilaksanakan sesuai dengan anggaran dasar serta memberi nasihat kepada direksi. Dewan komisaris tugas utamanya adalah melakukan pengawasan terhadap kebijakan pengurusan perseroan dan jalannya pengurusan pada umumnya yang dilakukan direksi.

Pengawasan juga dapat dilakukan oleh dewan komisaris terhadap sasarn atau objek tertentu, yakni:

a. Melakukan audit keuangan;

b. Pengawasan atas organisasi perseroan;

c. Pengawasan tehadap personalia.

Mengenai tugas dewan komisaris yaitu memberi nasihat kepada direksi dapat dilakukan dewan komisaris untuk hal yang spesifik dalam bentuk pendapat atau petunjuk seperti pembuatan rencana kerja yang proporsional untuk memajukan dan mengembangkan perusahaan sesuai prinsip good corporate governance.

Tugas pengawasan serta pemberian nasihat, kritik atau masukan terhadap direksi berdasarkan Pasal 108 UU Perseroan Terbatas adalah untuk kepentingan perseroan sesuai maksud dan tujuan perseroan. Maksud dari untuk kepentingan perseroan sesuai maksud dan tujuan adalah pengawasan dan nasihat yang berikan oleh dewan komisaris tidak untuk pihak tertentu.

3. Direksi

Direksi dalam suatu perseroan tugas utamanya ialah menjalankan pengurusan perseroan untuk kepentingan perseroan, secara umum pengertian pengurusan

22 Yahya Harahap. (2009). Hukum Perseroan Terbatas. Jakarta: Sinar Grafika, h. 307-308. 
perseroan oleh direksi dalam konteks melaksanakan kekuasaan pengadministrasian serta pemeliharaan harta kekayaan perseroan sesuai dengan ketentuan perundangundangan dan anggaran dasar perseroan.

Direksi merupakan pejabat perseroan dan oleh karena itu dia tidak berhak medapatkan pembayaran preferensial apabila perseroan di likuidasi. Pelaksanaan pengurusan meluputi pengurusan kegiatan perseroan sehari-hari, namun dalam berdasarkan Pasal 92 UU Perseroan Terbatas terdapat batas-batas untuk direksi dalam menjalankan kewenangannya, yakni :

a. Sesuai dan hanya untuk kepentingan perseroan;

b. Sesuai dengan maksud dan tujuan perseroan;

c. Sesuai dengan kebijakan yang dipandang tepat;

Yang dimaksud dengan kebijakan yang dipandang tepat ialah pengurusan dilakukan berdasarkan keahlian yang berarti kebijakan diambil berdasarkan pemahaman, pangalaman dan keterampilan yang sesuai dengan ilmu pengetahuan yang dimiliki direksi. Kebijakan juga dapat diambil berdasarkan peluang yang ada dan kelaziman yang ada dalam dunia usaha.

Guna menguji pertanggungjawaban masing-masing organ perseroan terbatas tersebut, Penulis menggunakan teori-teori dibawah ini sebagai bahan kajian:

\section{Doktrin Ultra Vires}

Doktrin ultra vires atau yang dikenal juga dengan doktrin pelampauan kewenangan merupakan salah satu doktrin yang dianut dalam UU Perseroan Terbatas. Berdasarkan doktrin ini segala tindakan organ perseroan atas nama perseroan yang diluar kewenangannya atau diluar kepentingan perseroan serta maksud dan tujuan perseroan tidak mengikat perseroan tersebut dan dianggap batal demi hukum.

\section{Doktrin Piercing of Corporate Veil}

Sebagaimana diketahui bahwa terdapat batasan pertanggung jawaban atas tindakan yang dilakukan para pemegang saham, direksi dan dewan komisaris, namun batasan tersebut dapat hapus dengan adanya doktrin ini asalkan dapat dibuktikan bahwa pemegang saham, direksi atau dewan komisaris melakukan tindakan diluar kewenangannya sebagaimana diatur dalam peraturan perundang-undangan dan anggaran dasar perseroan. Dalam prakteknya hal seperti ini baru dapat dibuktikan saat sengketa sudah masuk ke tahap pembuktian di pengadilan.

Akibat dari hapusnya batasan pertanggungjawaban tersebut ialah pihak yang bertanggung jawab harus menanggung sampai ke kekayaan pribadi. Dalam hal dewan komisaris melakukan suatu tindakan atas nama perseroan untuk kepentingannya sendiri atau tidak sesuai dengan anggaran dasar atau tidak sesuai dengan maksud dan tujuan perseroan dan ternyata akibat tindakan tersebut timbul kerugian maka dewan komisaris tesebut haruslah bertanggungjawab penuh atas kerugian yang ia sebabkan sampai ke kekayaan pribadinya, begitu pula berlaku untuk direksi dan pemegang saham. 


\section{B. Pertanggungjawaban Anggota Dewan Komisaris Atas Tindakan Pengurusan Yang Dilakukan Atas Nama Perseroan}

Perseroan terbatas merupakan suatau badan hukum yang nominal modal dasar, modal ditempatkan dan modal disetor tercantum dalam anggaran dasar perseroan, yang mana modal ditempatkan dan modal disetor merupakan kekayaan perseroan yang terpisah dari kekayaan para pendirinya. Dalam anggaran dasar perseroan itu pula dicantumkan nama perorangan-perorangan yang menjabat sebagai direksi dan dewan komisaris.

Sehubungan dengan penelitian ini berkaitan dengan dewan komisaris maka perlu diketahui secara normatif berdasarkan Pasal 108 UU Perseroan Terbatas tugas utama seorang dewan komisaris ialah melakukan pengawasan atas kebijakan pengurusan dan mengawasi jalannya pengurusan pada umumnya, baik mengenai perseroan maupun usaha perseroan dan memberikan nasihat kepada direksi.

Pada prakteknya sering terjadi dimana anggota dewan komisaris bertindak melampaui kewenangannya, ia tidak hanya melakukan pengawasan namun juga melakukan pengurusan bahkan mengadakan perikatan untuk dan atas nama perseroan dengan pihak ketiga, fenomena tersebut terjadi dalam perseroan terbatas yang pemegang sahamnya juga menjabat sebagai dewan komisaris. Hal ini jika dikaitkan dengan Pasal 114 ayat (2) dan(3) UU Perseroan Terbatas, maka jika terjadi kerugian yang dialami perseroan maka anggota dewan komisaris tersebut harus bertanggung jawab secara pribadi atas kerugian perseroan tersebut, begitu pula dengan kerugian yang dialami pihak ketiga maka anggota dewan komisaris tersebut juga harus bertanggung jawab atas kerugian itu, dalam keadaan tersebut anggota dewan komisaris telah melakukan tindakan yang dimaksud dalam doktrin piercing of corporate veil. Oleh karena itu menurut Penulis alangkah lebih baik jika para pendiri memahami terlebih dahulu kewenangan dan fungsi setiap organ dalam perseroan terbatas agar saat menjabat sebagai salah satu organ perseroan tidak melakukan kesalahan atau kelalaian yang bisa merugikan perseroan dan dirinya sendiri.

Pihak ketiga yang merasa dirugikan dapat mengajukan gugatan perbuatan melawan hukum berdasarkan Pasal 1365 Kitab Undang-Undang Hukum Perdata dan pemegang saham juga dapat menggugat anggota dewan komisaris yang melakukan kesalahan atau kelalaian yang menimbulkan kerugian ke pengadilan negeri asalkan pemegang saham tersebut mewakili paling sedikit 1/10 (satu per sepuluh) bagian dari jumlah seluruh saham. Berdasarkan Pasal 1365 Kitab Undang-Undang Hukum Perdata yang dimaksud dengan perbuatan melawan hukum adalah tindakan yang melawan hukun yang dilakukan oleh seseorang yang karena kesalahannya telah menimbulkan kerugian bagi pihak lain. Berdasarkan literatur-literatur hukum dikenal 3 (tiga) ciri dari perbuatan melawan hukum, yakni:

a. Perbuatan melawan hukum secara sengaja;

b. Perbuatan melawan hukum karena lalai;

c. Perbuatan melawan hukum tanpa adanya kesalahan (tidak ada unsur kesengajaan ataupun kelalaian). 
Apabila perseroan pailit dikarenakan kesalahan atau kelalaian dari dewan komisaris dalam melakukan pengawasan terhadap perseroan dan ternyata kekayaan perseroan tidak cukup untuk membayar seluruh kewajiban perseroan maka setiap anggota dewan komisaris secara tanggung renteng bertanggung jawab bersama direksi atas kewajiban yang belum dilunasi. Apabila terdapat kondisi dimana semua anggota direksi perseroan diberhentikan sementara, maka anggota dewan komisaris yang ditunjuk dapat menggantikan kedudukan direksi untuk sementara agar dapat melaksanakan kegiatan sehari-hari perseroan. Tindakan dewan komisaris ini tidaklah melampaui kewenangan, hal ini disebabkan adanya kondisi dimana direksi tidak dapat menjalankan kepengurusan untuk sementara. Kondisi seperti ini bisa terjadi apabila anggota direksi mempunyai benturan kepentingan atau telah merugikan perseroan.

Pertanggungjawaban secara pribadi pun tidak akan dikenakan kepada dewan komisaris yang telah melakukan pekerjaannya dengan benar walaupun perseroannya mengalami kerugian asalkan ia dapat membuktikan bahwa keadaan kerugian tersebut memang bukan disebabkan oleh kesalahan yang ia perbuat. Bisa saja ada kondisi dimana salah satu anggota dewan komisaris harus bertanggung jawab secara pribadi namun yang lain tidak, dalam keadaan tersebut masing-masing anggota dewan komisaris harus membuktikan bahwa mereka tidak melakukan kesalahan yang menyebabkan kerugian.

Mengenai dewan komisaris yang dapat dimintakan pertanggung jawabannya secara pribadi, hal tersebut tidak hanya dalam aspek perdata namun juga dapat secara pidana. Dalam putusan Mahkamah Agung Nomor: 1722K/Pid.Sus/2010 dengan terdakwa atas nama Suryadi Sentosa yang merupakan pemegang saham sekaligus anggota dewan komisaris perseroan dinyatakan bersalah. Pelaksanaan pertanggungjawaban tersebut sesuai dengan teori pertanggung jawaban yang dijelaskan oleh Ridwan Halim yaitu akibat lebih lanjut dari pelaksanaan peranan, baik peranan itu merupakan hak dan kewajiban ataupun kekuasaan, secara umum tanggung jawab hukum berarti kewajiban untuk melakukan sesuatu atau berprilaku menurut cara tertentu dan tidak menyimpang dari peraturan yang telah ada.

Perlu ditegaskan kembali bahwa untuk meminta dewan komisaris bertanggung jawab secara pribadi harus melalui dengan gugatan melalui pengadilan negeri, tidak bisa dilakukan dengan penyataan sepihak, selagi masih belum adanya putusan pengadilan yang memutuskan anggota dewan komisaris bertanggungjawab secara pribadi maka secara hukum kerugian yang ada masih tanggung jawab perseroan.

\section{PENUTUP}

Anggota dewan komisaris dapat melakukan pengurusan terhadap perseroan terbatas jika seluruh anggota direksi diberhentikan untuk sementara sehingga tidak ada satupun anggota direksi yang dapat melakukan pengurusan perseroan; anggota dewan komisaris barulah bertanggung jawab secara pribadi terhadap tindakan pengurusan yang dilakukanya untuk dan atas nama perseroan jika tidak sesuai dengan anggaran dasar, meksud dan tujuan serta kepentingan perseroan yang mana dari tindakannya tersebut muncul kerugian; pertanggungjawaban secara pribadi yang dimintakan kepada anggota 
dewan komisaris yang melakukan kesalahan tidak bisa hanya dengan penyataan sepihak, harus melalui proses gugatan di pengadilan; pertanggungjawaban secara pribadi tidak yang dapat dimintakan kepada dewan komsiaris tidak hanya dalam aspek perdata (ganti rugi) namun juga dalam aspek pidana.

Penulis dalam hal ini menyarankan bagi pihak yang ingin mendirikan perseroan terbatas sebaiknya untuk mengetahui lebih dalam mengenai badan hukum tersebut, salah satunya dengan memahami fungsi, kewenangan dan pertanggung jawaban dari masingmasing organ dalam perseroan terbatas. Dalam praktiknya banyak dewan komisaris yang tidak mengetahui batasan-batasan dari jabatannya sehingga pengurusan perseroan yang seharusnya dilakukan direksi dilakukan oleh dewan komisaris, untuk meminimalisir hal ini akan lebih baik pemegang saham yang berniat untuk melakukan pengurusan perseroan menjabat sebagai direksi sedangkan yang hanya ingin menanam modal menjabat sebagai dewan komisaris. Namun perlu diingat walaupun dewan komisaris tidak melakukan pengurusan tetap berkewajiban melakukan pengawasan.

\section{DAFTAR PUSTAKA}

H.M.N. Purwosutjipto. (1979). Pengertian Pokok Hukum Dagang Indonesia. Jakarta: Djambatan,.

Harahap, Yahya. (2009). Hukum Perseroan Terbatas. Jakarta: Sinar Grafika.

Kholil, Munawar. (26 Oktober 2020). “Catatan Kritis Perubahan Landscape Hukum

Perseroan Terbatas dalam Undang-Undang Cipta Kerja". Jurnal RechtsVinding.

Marzuki, Peter Mahmud. (2011). Pengantar Ilmu Hukum. Jakarta: Prenada Media Group.

Marzuki, Peter Mahmud. (2016). Penelitian Hukum. Jakarta: Prenada Media Group.

Soedjono Dirjosisworo. (1997). HukumPerusahaan Mengenai Bentuk-bentuk Perusahaan

(Badan Usaha) di Indonesia. Bandung : Mandar Maju,.

Undang-Undang Republik Indonesia Nomor 11 Tahun 2020 tentang Cipta Kerja

Undang-Undang Republik Indonesia Nomor 40 Tahun 2007 tentang Perseroan Terbatas 